\title{
A Sensitive Spectrophotometric Estimation of Nimodipine in Tablets and Injection Using Phloroglucinol
}

\author{
Hemavathi N. Deepakumari and Hosakere D. Revanasiddappa \\ Department of Chemistry, University of Mysore, Manasagangotri, Mysore 570 006, India \\ Correspondence should be addressed to Hosakere D. Revanasiddappa; hdrevanasiddappa@yahoo.com
}

Received 2 April 2013; Accepted 7 May 2013

Academic Editors: G. D’Errico and E. Stathatos

Copyright ( 2013 H. N. Deepakumari and H. D. Revanasiddappa. This is an open access article distributed under the Creative Commons Attribution License, which permits unrestricted use, distribution, and reproduction in any medium, provided the original work is properly cited.

\begin{abstract}
A rapid, simple, and sensitive spectrophotometric method has been described for the determination of nimodipine in bulk drug, tablets, and injection. The proposed method is based on the diazotization of reduced nimodipine with nitrous acid followed by coupling with phloroglucinol to form colored azo dye and showing absorption maximum $\left(\lambda_{\max }\right)$ at $410 \mathrm{~nm}$. The formed colored azo dye is stable for about more than $2 \mathrm{~h}$. The method obeyed Beer's law over the concentration range of $0-25 \mu \mathrm{g} / \mathrm{mL}$ and the corresponding molar absorptivity value is $1.23 \times 10^{4} \mathrm{~L} / \mathrm{moL} / \mathrm{cm}$. The Sandell sensitivity values limits of detection (LOD) and quantification (LOQ) values have also been reported for the developed method. The accuracy and precision of the method was evaluated on intra- and interday basis; the relative error (\%RE) and the relative standard deviation (RSD) were $<2.0 \%$. All variables have been optimized and the presented reaction sequence was applied to the analysis of nimodipine in bulk drug, tablets, and injections. The performance of this method was evaluated in terms of Student's $t$-test and variance ratio $F$-test to find out the significance of proposed method over the reference method.
\end{abstract}

\section{Introduction}

Nimodipine (NMD), chemically known as isopropyl-2methoxyethyl-1,4-dihydro-2,6-dimethyl-4-(3-nitrophenyl)3,5-pyridine dicarboxylate (Figure 1), is a dihydropyridine calcium channel blocker that acts by relaxing the arterial smooth muscle. It is known for its preferential action on cerebral blood vessels and its potential cytoprotective effects by reducing calcium influx into nerve cells [1]. Nimodipine has also been used in the other cerebrovascular disorders, such as ischemic stroke, hypertension, and multi-infarct dementia [2]. It increases blood flow to injured brain tissues. It has been officially determined by liquid chromatographic method with UV detection [3].

Various analytical methods for the measurement of this compound have been reported. These include HPLC [4], LC-MS-MS [5], LC-MS [6], and GC with electron capture detection [7]. These techniques are highly expensive and not affordable for the routine analysis of dosage forms. Various analytical techniques that have been reported for this drug in therapeutics include atomic absorption spectrophotometry [8], polarography [9], spectrofluorimetry [10], and spectrophotometry [11-16].

Many of the reported methods are time consuming and require expensive experimental setup [4-7], and polarographic methods are less sensitive [9]. Besides, the reported spectrophotometric methods are less sensitive [11-16] and require heating conditions [11] and costly chromogenic reagent [13], (Table 1). Considering these demerits, there was a need to develop more advantageous spectrophotometric method for the determination of NMD in bulk sample and in tablets.

The present investigation reports the development and validation of a simple, highly sensitive, and accurate method for the determination of NMD in bulk drug, tablets, and in injection based on diazo-coupling reaction using phloroglucinol (PG) as the coupling agent. The developed method is validated for linearity, accuracy, precision, selectivity, and recovery as per the current $\mathrm{ICH}$ guidelines. 
TABLE 1: Comparison of the performance characteristic of the existing visible spectrophotometric methods with the proposed methods.

\begin{tabular}{|c|c|c|c|c|c|}
\hline Sl no. & Reagent/s used & Methodology & $\begin{array}{c}\text { Linear range } \mu \mathrm{g} / \mathrm{mL} \\
\text { and molar } \\
\text { absorptivity } \\
\mathrm{L} / \mathrm{moL} / \mathrm{cm}\end{array}$ & Remarks & References \\
\hline (1) & $\begin{array}{l}\text { 4-Dimethylaminobenzaldehyde in } \\
\text { methanol }\end{array}$ & $\begin{array}{l}\text { Condensation product was } \\
\text { measured at } 580 \mathrm{~nm}\end{array}$ & - & $\begin{array}{l}\text { Requires heating } \\
\text { condition }\end{array}$ & {$[11]$} \\
\hline (2) & $\begin{array}{l}N \text {-(1-naphthyl)ethylenediamine } \\
\text { dihydrochloride }\end{array}$ & $\begin{array}{l}\text { Colored azo dye was } \\
\text { measured at } 550 \mathrm{~nm}\end{array}$ & $0-40.0$ & Less sensitive & {$[12]$} \\
\hline (3) & $\begin{array}{l}\text { (a) p-Dimethylaminocinnamaldehyde } \\
\text { (b) Folin Ciocalteu reagent }\end{array}$ & $\begin{array}{l}\text { The absorbance of Schiff base } \\
\text { was measured at } 510 \mathrm{~nm} \\
\text { The colored complex was } \\
\text { measured at } 640 \mathrm{~nm}\end{array}$ & $\begin{array}{c}0.5-4.0 \\
5.0-25.0\end{array}$ & $\begin{array}{l}\text { Sensitive but uses } \\
\text { costly reagent } \\
\text { Lack of selectivity }\end{array}$ & {$[13]$} \\
\hline (4) & $\beta$-Naphthol & $\begin{array}{l}\text { Orange-red colored azo dye } \\
\text { measured at } 555 \mathrm{~nm}\end{array}$ & $\begin{array}{c}0-10.0 \\
\left(€=7.74 \times 10^{2}\right)\end{array}$ & Less sensitive & {$[14]$} \\
\hline (5) & Metol-dichromate & $\begin{array}{l}\text { Charge transfer complex } \\
\text { measured at } 520 \mathrm{~nm}\end{array}$ & $\begin{array}{c}0-70.0 \\
\left(€=3.15 \times 10^{3}\right)\end{array}$ & $\begin{array}{l}\text { Less sensitive and } \\
\text { requires strict } \mathrm{pH} \\
\text { control }\end{array}$ & {$[15]$} \\
\hline (6) & Phloroglucinol & $\begin{array}{l}\text { Yellow colored azo dye } \\
\text { measured at } 410 \mathrm{~nm}\end{array}$ & $\left(€=1.23 \times 10^{4}\right)$ & $\begin{array}{l}\text { Highly sensitive and } \\
\text { has wider linear } \\
\text { dynamic ranges }\end{array}$ & $\begin{array}{l}\text { Proposed } \\
\text { method }\end{array}$ \\
\hline
\end{tabular}<smiles>COCCOC(=O)C1=C(C)NC(C)=C(C(=O)OC(C)C)C1c1cccc([N+](=O)[O-])c1</smiles>

FIGURE 1: Structures of NMD.

\section{Experimental Section}

2.1. Apparatus. All spectral and absorbance measurements were performed using a Systronics Model 166 digital spectrophotometer provided with $1 \mathrm{~cm}$ matched silica quartz cells.

2.2. Reagents and Standards. Analytical reagent grade chemicals and reagents were used, and double distilled water was used throughout the experiment to prepare all solutions.

(i) Standard NMD solution. The pharmaceutical grade NMD certified to be $99.99 \%$ pure was received from (Cipla Ltd., Mumbai, India) as a gift sample and used as received. Accurately $10 \mathrm{mg}$ each of NMD was weighed into a $100 \mathrm{~mL}$ beaker and dissolved NMD in $5 \mathrm{~mL}$ acetone. To this, $5 \mathrm{~mL} 4 \mathrm{~N}$ hydrochloric acid and $1 \mathrm{~g}$ of zinc dust were added and shaken thoroughly for about $15 \mathrm{~min}$ and then diluted up to the mark with water in a $100 \mathrm{~mL}$ calibrated flask $(100 \mu \mathrm{g} / \mathrm{mL})$, and filter through Whatman number 41 filter paper. Working solutions were prepared as required by dilution.

Pharmaceutical formulations of NMD such as Nimodip (Cadila) and Nimotide (Micro synapse) tablets and Modipin (Torrent) injection were purchased from local markets.

(ii) Phloroglucinol $[\mathrm{PG}][1 \% \mathrm{w} / \mathrm{v}]$. It was prepared by dissolving $1 \mathrm{~g}$ of the phloroglucinol (99.98\%) (BDH Chemicals Ltd., Poole, England) in $100 \mathrm{~mL}$ distilled water.

(iii) Others. Aqueous solutions of sodium nitrite [0.1\%] (Merck), sulfamic acid [3.0\% w/v] (Qualigens), sodium hydroxide [4 M] (Merck), and hydrochloric acid $[1 \mathrm{M}]($ Merck) were prepared and used.

2.3. Preparation of Calibration Graph. Aliquot of nimodipine ranging from 0 to $25 \mu \mathrm{g} / \mathrm{mL}$ was transferred into a series of $10 \mathrm{~mL}$ volumetric flasks. To each flask, $0.5 \mathrm{~mL}$ sodium nitrite $(0.1 \% \mathrm{w} / \mathrm{v})$ and $1 \mathrm{~mL}$ of $1 \mathrm{M}$ hydrochloric acid were added. After $3 \mathrm{~min}, 0.5 \mathrm{~mL}$ of sulfamic acid $(3 \% \mathrm{w} / \mathrm{v})$ was added to each flask. Then, $1 \mathrm{~mL}$ of phloroglucinol (1\% w/v) and $1.5 \mathrm{~mL}$ $4 \mathrm{M}$ sodium hydroxide were added. The contents were made up to the mark with distilled water and mixed well. After $5 \mathrm{~min}$, the absorbance of the yellow colored azo dye was measured at $410 \mathrm{~nm}$ against the reagent blank. The amount of nimodipine present in the sample was computed from the calibration curve.

\subsection{Procedure for Commercial Samples}

2.4.1. Procedure for Tablets. Twenty tablets were weighed accurately and ground into a fine powder. Tablets powder equivalent to $10 \mathrm{mg}$ of the NMD was accurately weighed and dissolved in $5 \mathrm{~mL}$ of methanol. To this, $5 \mathrm{~mL} 4 \mathrm{~N}$ hydrochloric acid and $1 \mathrm{~g}$ of zinc dust were added into a $100 \mathrm{~mL}$ volumetric flask and shaken thoroughly for about $30 \mathrm{~min}$. The volume was made up to the mark with water, mixed well and filtered using Whatman number 41 filter paper. Appropriate 


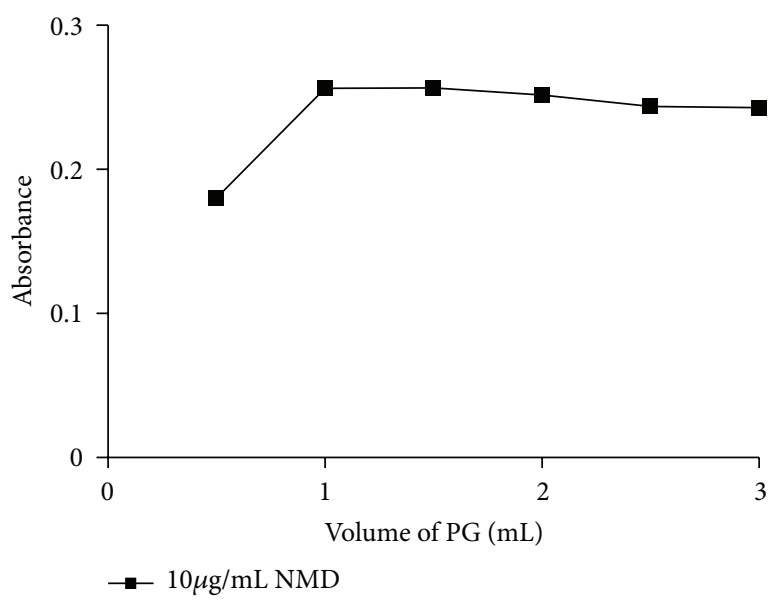

(a)

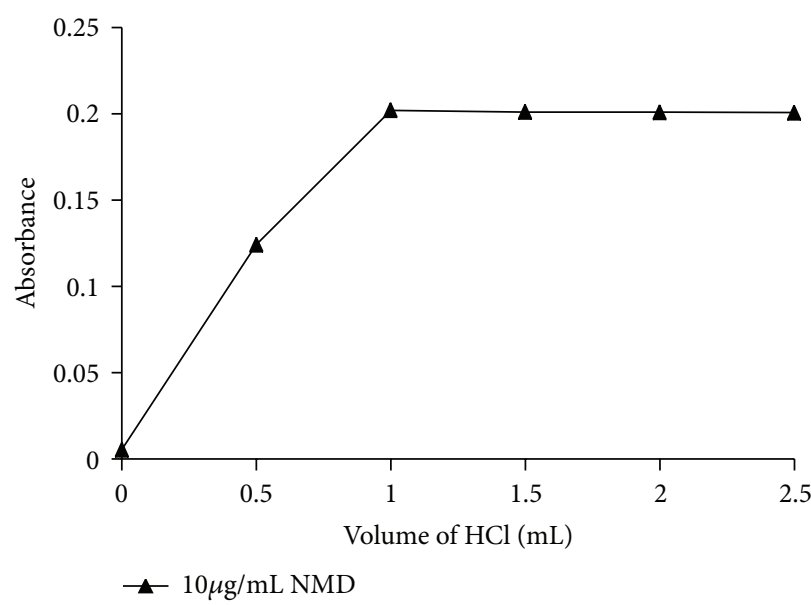

(c)

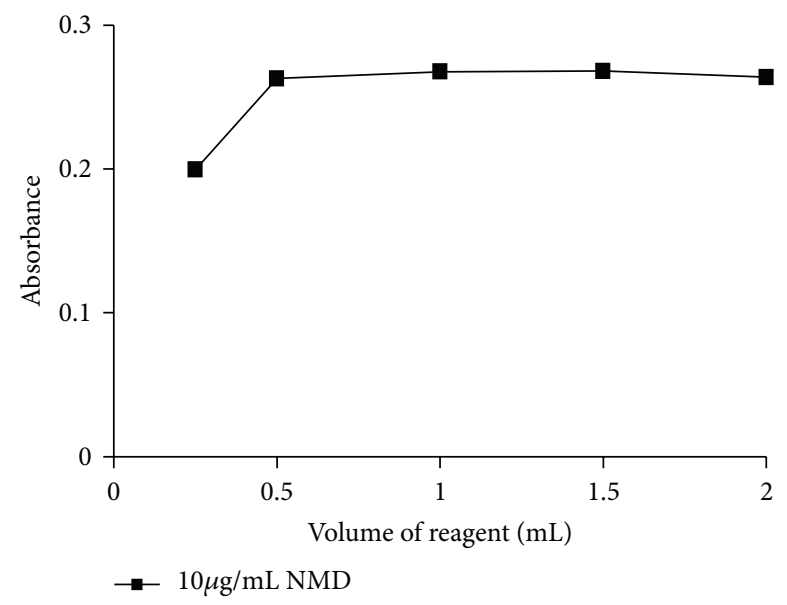

(b)

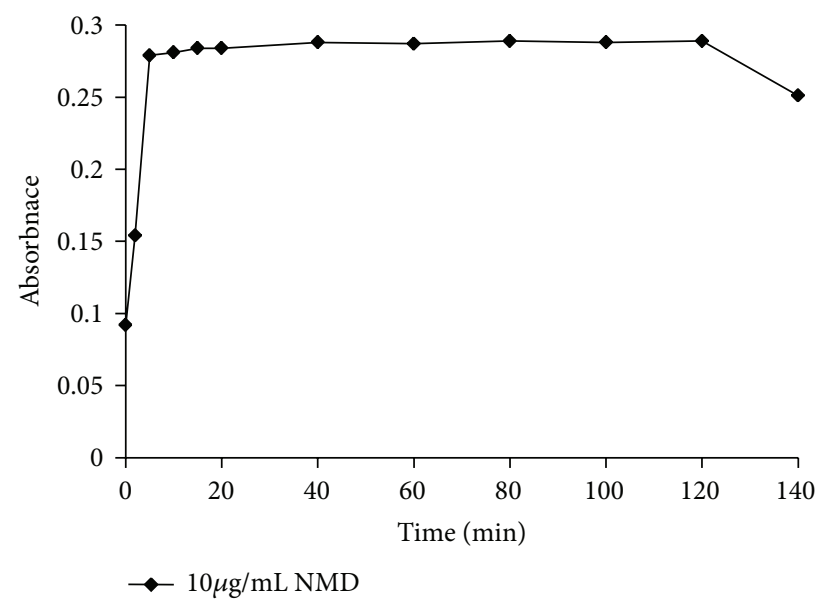

(d)

FIGURE 2: (a) Effect of reagent. (b) Effect of sodium nitrite. (c) Effect of Hydrochloric acid. (d) Effect of time.

aliquots of the drug solution were taken, and the proposed standard procedure was followed for analysis of the drug content.

2.4.2. Procedure for Injection. Nimodipine injection sample such as Modipin (Torrent) was transferred into a $100 \mathrm{~mL}$ calibrated flask. Then, the volume was diluted to the mark with distilled water and mixed well. The content of the flask which was at a concentration of $100 \mu \mathrm{g} / \mathrm{mL}$ was subjected to analysis by the procedure described above after suitable dilution step.

\section{Results and Discussion}

3.1. Chemistry. In the developed method, the aromatic amino group in reduced nimodipine undergoes diazotization with nitrous acid and then couples the resulting diazonium salt with phloroglucinol to form yellow colored azo dye and exhibits absorption maximum $\left(\lambda_{\max }\right)$ at $410 \mathrm{~nm}$. The colored azo dye formed is stable for more than $2 \mathrm{~h}$. Two steps are involved in the reaction that produces the colored azo dyes. In the first step, reduced NMD is treated with nitrite solution in hydrochloric acid medium and undergoes diazotization to give diazonium ion. In the second step, the diazonium ion is coupled with the coupling agent phloroglucinol to form colored azo dyes in alkaline medium $[17,18]$. Based on the above observations, a simple spectrophotometric method to the determination of NMD was developed and validated as per the current ICH guidelines (see Scheme 1).

3.2. Optimization of Experimental Parameters. The various experimental parameters, which influence the formation of the colored azo dye, were optimized.

3.2.1. Effect of Reagents. In order to study the effect of concentration of phloroglucinol, a fixed concentration of NMD $(10 \mu \mathrm{g} / \mathrm{mL})$ was taken in a series of $10 \mathrm{~mL}$ calibrated flasks, and to that $0.5-3 \mathrm{~mL}$ of phloroglucinol $(1 \% \mathrm{w} / \mathrm{v})$ was added and studied by measuring the absorbance at specified wavelengths in the standard procedure. Optimization is done by varying one parameter, keeping others constant. A volume of $1 \mathrm{~mL}$ phloroglucinol (1\%) in a total volume of $10 \mathrm{~mL}$ was found to be sufficient leading to maximum color stability of the azo dye (Figure 2(a)). 
<smiles>[R4]N(C)C(C)(C)C(N)=O</smiles><smiles>COCCOC(=O)C1=C(C)NC(C)=C(C(=O)OC(C)C)C1c1cccc(/N=N/c2c(O)cc(O)cc2O)c1</smiles>

Scheme 1: Proposed reaction scheme for NMD.

The constant absorbance readings were obtained in the range $0.25-2.0 \mathrm{~mL}$ of $0.1 \%$ sodium nitrite (Figure $2(\mathrm{~b})$ ). Thus, $0.5 \mathrm{~mL}$ of sodium nitrite solution was used in a total volume of $10 \mathrm{~mL}$ of reaction mixture. The excess of nitrite could be removed by the addition of $0.5 \mathrm{~mL}$ of $3 \%$ sulfamic acid.

3.2.2. Effect of Acid Concentration. Diazotization was carried out at room temperature, and cooling to $0-5^{\circ} \mathrm{C}$ was not necessary. The hydrochloric acid concentration was studied (Figure 2(c)), and $1 \mathrm{~mL}$ of $0.1 \mathrm{M}$ hydrochloric acid concentration was fixed for getting a stable diazonium ion in a $10 \mathrm{~mL}$ reaction mixture at room temperature $\left(27 \pm 3^{\circ} \mathrm{C}\right)$.

3.2.3. Effects of Alkali. In the developed method, the optimum concentration of sodium hydroxide leading to a maximum intensity of the yellow colored azo dye was found to be $1 \mathrm{~mL}$ of $4 \mathrm{M}$ in the final solution. Higher concentrations of alkali may lead to partial decolorization of the dye.

3.2.4. Effects of Reaction Time and Stability of the Azo Dye. Experiment was carried out to optimize the reaction time and stability of the azo dye. The colored azo dye developed rapidly after addition of the reagents and attained maximum intensity after about $5 \mathrm{~min}$ at room temperature. Stability study of the azo dye was carried out by measuring the absorbance values at time intervals of $10 \mathrm{~min}$ and was found to be stable for more than $2 \mathrm{~h}$ (Figure 2(d)).

3.3. Method Validation. The spectrophotometric method validation characteristics were tested in accordance with ICH
TABLE 2: Optical characteristics and precision.

\begin{tabular}{lc}
\hline Parameter & Proposed method \\
\hline$\lambda_{\max } \mathrm{nm}$ & 410 \\
Beer's law range $(\mu \mathrm{g} / \mathrm{mL})$ & $0-25$ \\
Linearity range $(\mu \mathrm{g} / \mathrm{mL})$ & $0.2-23$ \\
Molar absorptivity $(\varepsilon),(\mathrm{L} / \mathrm{mol} / \mathrm{cm})$ & $1.23 \times 10^{4}$ \\
Sandell's sensitivity $\left(\mu \mathrm{g} \mathrm{cm}^{-2}\right)$ & 0.034 \\
Intercept $(a)$ & -0.014 \\
Slope $(b)$ & 0.030 \\
Correlation coefficient $(r)$ & 0.997 \\
$S_{a}$ & 0.021 \\
$S_{b}$ & 0.001 \\
LOQ $(\mu \mathrm{g} / \mathrm{mL})$ & 0.189 \\
LOD $(\mu \mathrm{g} / \mathrm{mL})$ & 0.063 \\
\hline
\end{tabular}

${ }^{*} y=b c+a$ where $c$ is the concentration of NMD in $\mu \mathrm{g} / \mathrm{mL}$ and $y$ is the absorbance at $410 \mathrm{~nm}$. $S_{a}$ is the standard deviation of intercept, and $S_{b}$ is the standard deviation of slope.

$[19,20]$ guidelines. The proposed method was evaluated under the optimum conditions with respect to linearity, accuracy, precision, molar absorptivity, Sandell's sensitivity, and Student's $t$-test.

3.3.1. Linearity, Detection, and Quantitation Limit. A linear calibration graph was constructed using a standard solution of NMD. Under established experimental conditions, a linear correlation was found between the absorbance at $410 \mathrm{~nm}$ 
TABLE 3: Evaluation of intraday and interday accuracy and precision results.

\begin{tabular}{|c|c|c|c|c|c|c|c|}
\hline & \multirow{2}{*}{ NMD taken $\mu \mathrm{g} / \mathrm{mL}$} & \multicolumn{3}{|c|}{ Intraday $^{\mathrm{a}}$} & \multicolumn{3}{|c|}{ Interday $^{\mathrm{b}}$} \\
\hline & & $\mathrm{NMD}_{\text {found }}{ }^{\mathrm{c}} \mu \mathrm{g} / \mathrm{mL}$ & Precision $^{\mathrm{d}}$ & Accuracy $^{\mathrm{e}}$ & $\mathrm{NMD}$ found ${ }^{\mathrm{c}} \mu \mathrm{g} / \mathrm{mL}$ & Precision $^{\mathrm{d}}$ & Accuracy $^{e}$ \\
\hline \multirow{3}{*}{ Proposed method } & 10 & $9.94 \pm 0.09$ & 0.86 & 0.62 & $9.87 \pm 0.15$ & 1.55 & 1.29 \\
\hline & 15 & $14.92 \pm 0.05$ & 0.30 & 0.53 & $14.77 \pm 0.23$ & 1.56 & 1.56 \\
\hline & 20 & $20.07 \pm 0.05$ & 0.25 & -0.34 & $20.17 \pm 0.33$ & 1.62 & -0.86 \\
\hline
\end{tabular}

${ }^{a}$ Mean value of five determinations; ${ }^{b}$ mean value of five determinations; ${ }^{c}$ mean value of three determinations; ${ }^{\mathrm{d}}$ relative standard deviation (\%); ${ }^{\mathrm{e}}$ bias\%: (foundtaken/taken) $\times 100$.

TABLE 4: Results of determination of NMD in tablets and statistical comparison with the reference method.

\begin{tabular}{|c|c|c|c|}
\hline \multirow{2}{*}{ Tablet brand name* } & \multirow{2}{*}{ Nominal amount mg per tablet } & \multicolumn{2}{|c|}{ Found $^{* *}(\%$ of nominal amount $\pm \mathrm{SD}$ ) } \\
\hline & & Reference method [14] & Method \\
\hline \multirow{2}{*}{ Nimodip $^{a}$} & \multirow{2}{*}{$30 \mathrm{mg}$} & \multirow{2}{*}{$99.20 \pm 0.38$} & $100.27 \pm 0.62$ \\
\hline & & & $t=0.11, F=2.68$ \\
\hline \multirow{2}{*}{ Nimotide $^{b}$} & \multirow{2}{*}{$30 \mathrm{mg}$} & \multirow{2}{*}{$99.34 \pm 0.43$} & $100.54 \pm 0.41$ \\
\hline & & & $t=0.12, F=0.89$ \\
\hline \multirow{2}{*}{ Modipin $^{c}$} & \multirow{2}{*}{$30 \mathrm{mg} /$ injection } & \multirow{2}{*}{$100.02 \pm 0.53$} & $100.28 \pm 0.66$ \\
\hline & & & $t=0.03, F=1.53$ \\
\hline
\end{tabular}

${ }^{*}$ Marketed by; ${ }^{\mathrm{a}}$ Cadila; ${ }^{\mathrm{b}}$ Micro Synapse; ${ }^{\mathrm{c}}$ Torrent.

${ }^{* *}$ Mean value of five determinations.

Tabulated $t$ - and $F$-values at $95 \%$ confidence level are 2.77 and 6.39 , respectively.

and concentrations of NMD in the ranges given in Table 2. Regression analysis of the calibration curve is described by

$$
Y=a+b x
$$

where $y=$ absorbance, $a=$ intercept, $b=$ slope, and $x=$ concentration, and the values are presented in Table 2 . The optical characteristics such as absorption maxima, Beer's law limit, molar absorptivity, and Sandell's sensitivity values [21] are also given in Table 2 .

\subsubsection{Accuracy and Precision}

Precision and Accuracy. The intraday and interday precision of the proposed method was established by replicate analysis of NMD samples at three different concentrations (low, medium, and high) (Table 3) within the working limits, each being repeated five times. The percentage relative standard deviation (\% RSD) values of both intra- and interday studies are shown in Table 3 were satisfactory and showed the best appraisal of the procedures in daily use. Accuracy was evaluated as percentage relative error (\% RE) between the measured mean concentrations and taken concentrations for NMD. Bias $\{$ bias $\%=[$ (Concentration found-known concentration $) \times 100 /$ known concentration] $\}$ was calculated at each concentration, and the results obtained from this investigation are also summarized in Table 3 . The values percentage relative error between the concentrations of NMD for taken and found less than $2 \%$ showed the high accuracy of the proposed method. The proposed method was successfully applied to the determination of NMD in pharmaceutical dosage forms.
3.3.3. Selectivity. The selectivity of the proposed method to pharmaceutical samples was tested by a placebo blank and synthetic mixture analyses. A placebo blank containing starch (10 mg), acacia (10 mg), methyl cellulose (20 mg), sodium citrate $(15 \mathrm{mg})$, talc $(15 \mathrm{mg})$, magnesium stearate $(10 \mathrm{mg})$, and sodium alginate $(15 \mathrm{mg}$ ) was prepared by combining all components, and its solution was prepared as described under "procedure for tablets" and was subjected to analysis by following the general procedures. It was found that, there was no interference from the common excipients added to the tablets.

A synthetic mixture was separately prepared by adding pure NMD (10 mg) to placebo blank of similar composition and homogenized. The extract was prepared by taking synthetic mixture containing NMD (10 mg in $100 \mathrm{~mL})$ to give NMD $(100 \mu \mathrm{g} / \mathrm{mL})$. Synthetic mixture solution prepared above was taken at three different concentrations equivalent to 10,15 , and $20 \mu \mathrm{g} / \mathrm{mL}$ and was subjected to analysis by following the general procedure. The results of the study indicate that the common excipients did not interfere with the analysis by the proposed method and the results were obtained in the range from $98 \%$ to $101.5 \%$. These results complemented the findings of the placebo blank analysis with respect to selectivity.

3.3.4. Application to the Tablets and Injection. The proposed method was applied successfully to the determination of NMD in commercial tablets and injection. The same batch tablets were also assayed by the reference method [14] which consisted of measurement of absorbance of NMD at $550 \mathrm{~nm}$. The results of an assay were statistically compared with 
TABLE 5: Results of recovery by standard-addition method.

\begin{tabular}{lcccc}
\hline Tablet brand name & NMD tablet $\mu \mathrm{g} / \mathrm{mL}$ & Pure NMD added $\mu \mathrm{g} / \mathrm{mL}$ & Total found $\mu \mathrm{g} / \mathrm{mL}$ & Pure NMD recovered $\% \pm$ SD \\
\hline \multirow{3}{*}{ Nimodip } & 5 & 5 & 10.03 & $100.62 \pm 0.38$ \\
& 5 & 10 & 14.97 & $99.76 \pm 0.83$ \\
\hline \multirow{3}{*}{ Nimotide } & 5 & 15 & 20.07 & $100.44 \pm 0.65$ \\
& 5 & 5 & 10.05 & $101.05 \pm 0.66$ \\
& 5 & 10 & 15.02 & $100.19 \pm 0.33$ \\
Modipin & 5 & 15 & 20.05 & $100.35 \pm 0.22$ \\
& 5 & 5 & 9.99 & $99.85 \pm 0.53$ \\
& 5 & 10 & 14.99 & $99.97 \pm 0.69$ \\
\end{tabular}

${ }^{*}$ Mean value of three measurements.

the reference method [14] by applying the Student's $t$-test for accuracy and $F$-test for precision. The results in Table 4 showed that there is no significant difference between the proposed and reference method [14] at the 95\% confidence level with respect to accuracy and precision.

3.3.5. Recovery. To further assess the accuracy of the proposed method, recovery experiment was performed by applying the standard addition technique. The recovery test was done by adding nimodipine to the previously analyzed tablets. The recovery of each drug was calculated by comparing the concentration obtained from the spiked mixtures with those of pure drugs. The results are summarized in Table 5.

\section{Conclusions}

In the present investigation, a simple, highly sensitive, accurate, and precise spectrophotometric method for the routine estimation of NMD in pure form, tablets, and injection is described. The proposed method has better linear dynamic ranges and sensitivity compared to the reported visible [1014] spectrophotometric method. The main advantages of the established method are as follow.

(i) Diazotization was carried out at room temperature, and cooling to $0-5^{\circ} \mathrm{C}$ was not necessary.

(ii) The amount of the reagents used in the reaction is minimum. In addition, organic solvent are not used in the determination.

Furthermore, the proposed method does not require elaborate procedures, which are usually associated with chromatographic methods and other traditional extractive spectrophotometric methods. The methods are unaffected by slight variations in the experimental conditions such as basicity, reagent concentrations, and temperature. These advantages give the proposed method a great value and make it applicable for the analysis of NMD in routine quality control pharmaceutical laboratories.

\section{Acknowledgments}

The authors are grateful to Cipla Ltd., India, for the generous supply of pure drug sample. One of the authors
H. N. Deepakumari is thankful to the University of Mysore, Mysore, for providing necessary facilities.

\section{References}

[1] M. S. Langley and E. M. Sorkin, "Nimodipine: a review of its pharmacodynamic and pharmacokinetic properties, and therapeutic potential in cerebrovascular disease," Drugs, vol. 37, no. 5, pp. 669-699, 1989.

[2] J. E. F. Reynolds Martindale, The Extra Pharmacopeia, Pharmaceutical Press, London, UK.

[3] G. Ragno, M. Veronico, and C. Vetuschi, "Analysis of nimodipine and its photodegradation product by derivative spectrophotometry and gas chromatography," International Journal of Pharmaceutics, vol. 119, no. 1, pp. 115-119, 1995.

[4] D. B. Yang, J. B. Zhu, R. Q. Lv, Z. G. Hu, and J. Q. Shen, "Liquid chromatographic method for determination of free and niosome-entrapped nimodipine in mouse plasma and different tissues," Analalytical Letters, vol. 41, pp. 533-542, 2008.

[5] F. Qiu, X. Chen, X. Li, and D. Zhong, "Determination of nimodipine in human plasma by a sensitive and selective liquid chromatography-tandem mass spectrometry method," Journal of Chromatography B, vol. 802, no. 2, pp. 291-297, 2004.

[6] W. M. Muck, "Enantiospecific determination of nimodipine in human plasma by liquid chromatography-tandem mass spectrometry," Journal of Chromatography A, vol. 712, no. 1, pp. 45-53, 1995.

[7] P. Jakobsen, E. O. Mikkelsen, J. Laursen, and F. Jensen, “Determination of nimodipine by gas chromatography using electroncapture detection; External factors influencing nimodipine concentrations during intravenous administration," Journal of Chromatography, vol. 374, no. 2, pp. 383-387, 1986.

[8] M. Canlica and S. Islimyeli, “The atomic absorption spectrophotometric method for indirect determination of nimodipine in tablets," Turkish Journal of Chemistry, vol. 29, no. 2, pp. 141-146, 2005.

[9] J. A. Squella, J. C. Sturm, R. Lenac, and L. J. NunezVergara, "Polarographic and spectrophotometric determination of nimodipine in tablets," Analytical Letters, vol. 25, pp. 281-292, 1992.

[10] F. Belal, A. A. Al-Majed, S. Julkhuf, and N. Y. Khalil, "Spectrofluorometric determination of nimodipine in dosage forms and human urine," Pharmazie, vol. 58, no. 12, pp. 874-876, 2003. 
[11] S. Nirmala Bharathi, M. S. Prakash, M. Nagarajan, and K. Asok Kumar, "Spectrophotometric determination of nimodipine and its formulations," Indian Drugs, vol. 36, no. 10, pp. 661-662, 1999.

[12] K. P. R. Chowdary and G. Devala Rao, "A new spectrophotometric method for the determination of nimodipine," Indian Drugs, vol. 32, no. 11, pp. 548-550, 1995.

[13] M. N. Reddy, T. K. Murthy, K. V. Rao Kanna, A. V. Gopal Hara, and D. G. Sankar, "New spectrophotometric methods for the determination of nimodipine," Indian Drugs, vol. 38, no. 3, pp. 140-142, 2001.

[14] V. Ravichandran, M. T. Sulthan, A. Shameen, M. Balakumar, S. Raghuraman, and V. Sankar, "Spectrophotometric method for the determination of nimodipine in pharmaceutical dosage forms," Indian Journal of Pharmaceutical Science, vol. 63, pp. 425-427, 2001.

[15] H. D. Revanasiddappa, S. M. Mallegowda, H. N. Deepakumari, and K. B. Vinay, "Spectrophotometric determination of nitrazepam and nimodipine in pure and the tablet dosage forms," Asian Journal of Biochemical and Pharmaceutical Research, vol. 1, pp. 70-77, 2011.

[16] H. D. Revanasiddappa, S. M. Mallegowda, H. N. Deepakumari, and K. B. Vinay, "Spectrophotometric methods for the determination of nimodipine in pure and in pharmaceutical preparations," Jordan Journal of Chemistry, vol. 6, pp. 413-422, 2011.

[17] H. D. Revanasiddappa, H. N. Deepakumari, S. M. Mallegowda, and K. B. Vinay, "Facile spectrophotometric determination of nimodipine and nitrazepam in pharmaceutical preparations," Analele Universităţii din Bucureşti-Chimie, vol. 20, pp. 189-196, 2011.

[18] H. D. Revanasiddappa, S. M. Mallegowda, H. N. Deepakumari, and K. B. Vinay, "Spectrophotometric methods for the determination of nimodipine in pure and in pharmaceutical preparations," Jordan Journal of Chemistry, vol. 6, pp. 413-422, 2011.

[19] ICH, "Note for Guidance on Validation of Analytical Procedures: Methodology Q2B," 1996.

[20] International Conference On Harmonization of Technical Requirements for Registration of Pharmaceuticals for Human Use, ICH Harmonised Tripartite Guideline, Validation of Analytical Procadures: Text and Methodology Q2(R 1), Complimentary Guideline on Methodology, dated 06 November 1996, London, UK, November 2005.

[21] H. Zavis, D. Ludvik, K. Milan, S. Liadidlaw, and V. Frantisk, Handbook of Organic Reagents in Inorganic Anaslysis, Eds: University of Aberdem, Ellis Horwood Limited, John Wiley \& Sons, London, UK, 1976. 

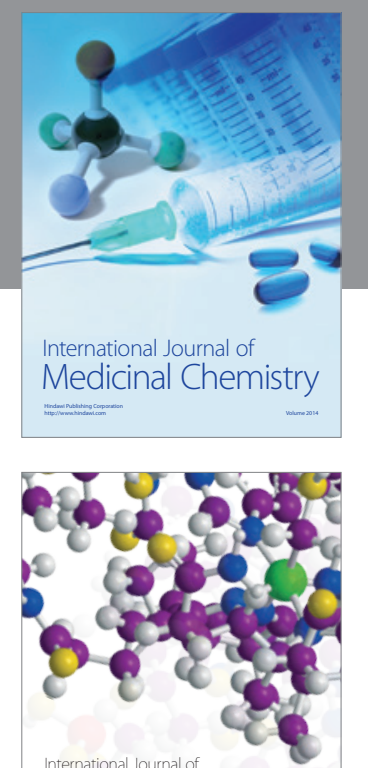

\section{Carbohydrate} Chemistry

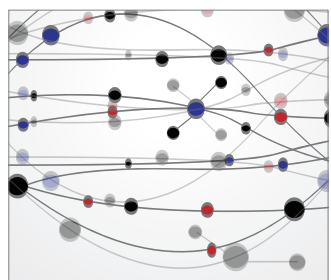

The Scientific World Journal
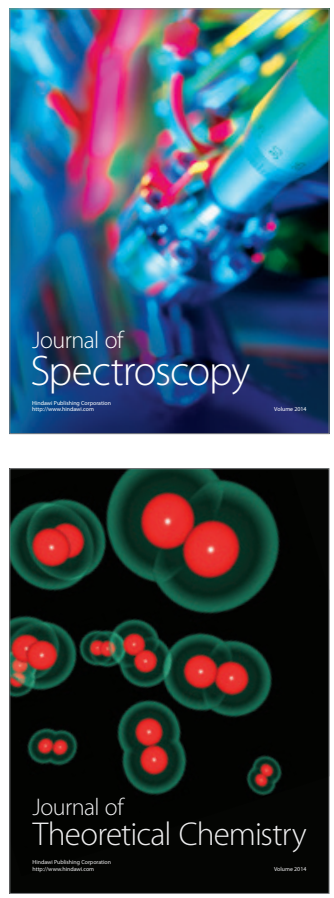
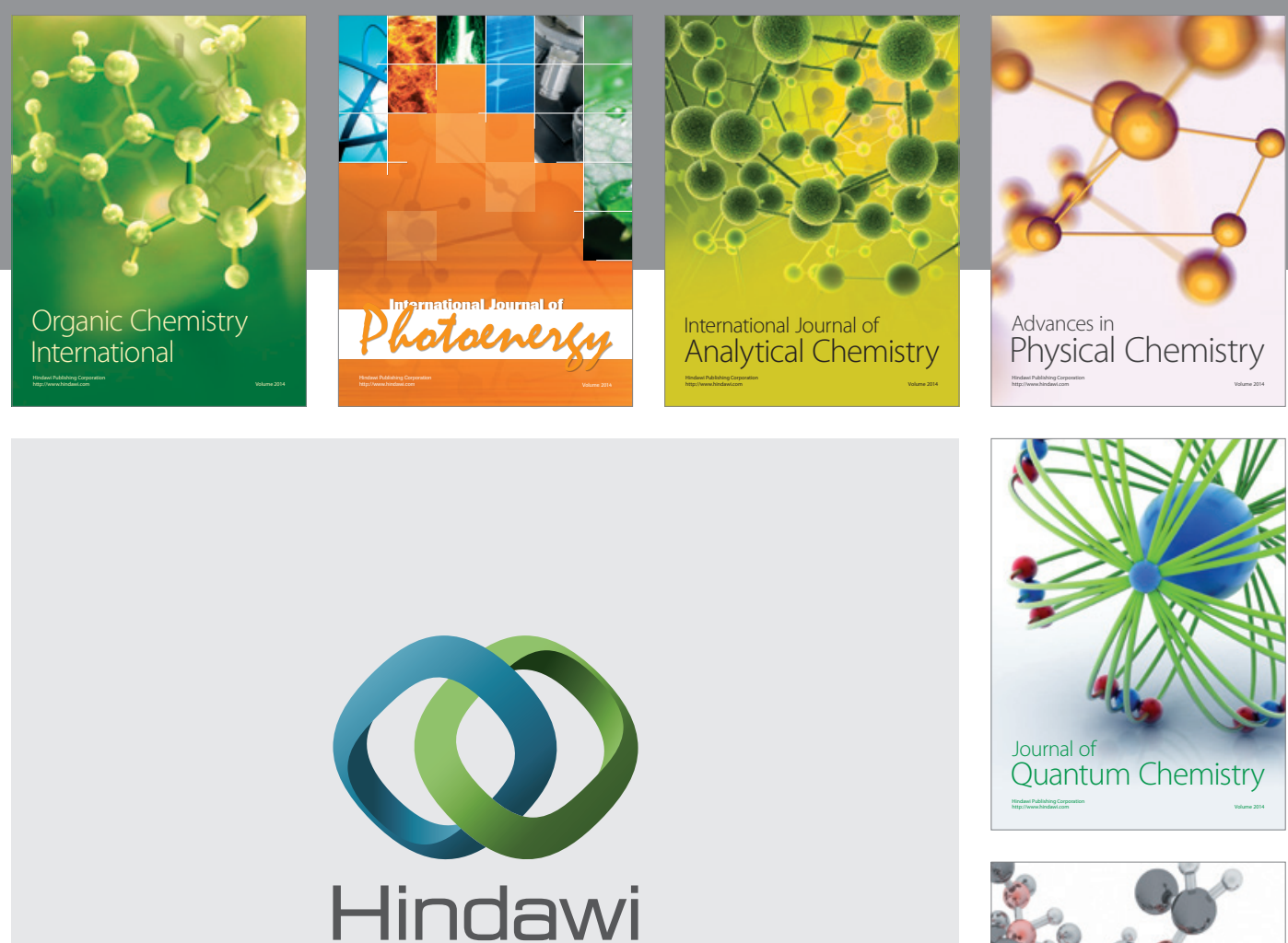

Submit your manuscripts at

http://www.hindawi.com

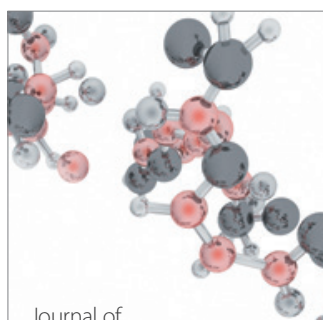

Analytical Methods

in Chemistry

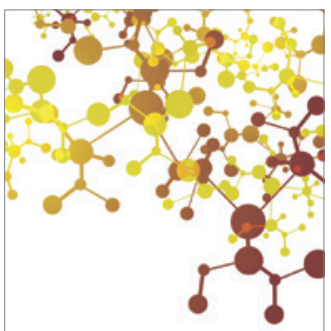

Journal of

Applied Chemistry

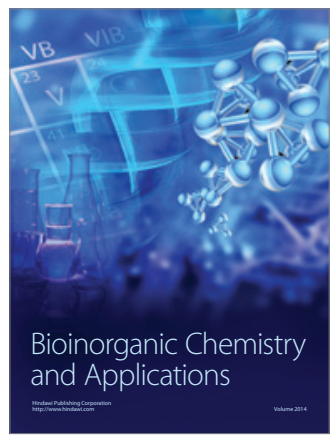

Inorganic Chemistry
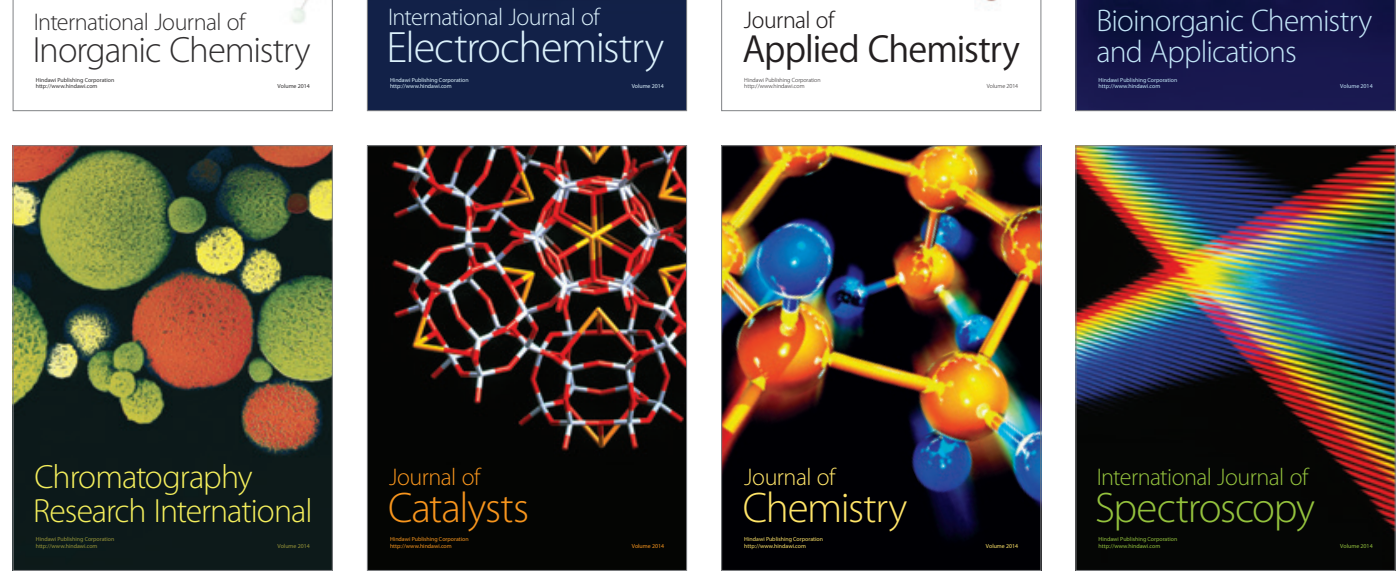